\title{
Combining 2-iminobiotin and hypothermia for reducing hypoxia-induced neuronal damage: Implications from a human cell culture model of hypoxic-ischemic brain injury
}

\author{
Zitta K. ${ }^{1}$, Peeters-Scholte C. ${ }^{2}$, Sommer L. ${ }^{1}$, Parczany K ${ }^{1}$, Steinfath M. ${ }^{1}$, Albrecht M. ${ }^{1}$
}

${ }^{1}$ Department of Anesthesiology and Intensive Care Medicine, University Hospital Schleswig-Holstein, Campus Kiel, Germany. ${ }^{2}$ Neurophyxia B.V.,'s-Hertogenbosch, The Netherlands.

Background: Perinatal asphyxia represents one of the major causes of neonatal morbidity and mortality. Hypothermia is currently the only established treatment for hypoxic-ischemic encephalopathy, and no specific pharmacological therapy exists so far. We and others have shown that the biotin analogue 2-iminobiotin (2-IB) is able to reduce neuronal cell damage both in vitro as well as in vivo under normothermic conditions.

\section{The aim of this study was to evaluate whether 2-IB has the potential to attenuate hypoxia-induced injury of} neuronal cells under hypothermic conditions.

Materials and methods: In-vitro hypoxia was induced for $7 \mathrm{~h}$ using IMR-32 cell cultures in combination with our described enzyme based hypoxia model. After the hypoxic insult, cultures were incubated at $33.5^{\circ} \mathrm{C}$ (hypothermia), with vehicle (citrate $1 \%$ ) or different concentrations of 2-IB (10,30, 50, 100 and $300 \mathrm{ng} / \mathrm{ml}$ ). A schematic representation of the applied protocol is shown in Fig. 1A. Cell morphology was evaluated by brightfield microscopy and cell damage was analyzed by lactate dehydrogenase (LDH) assays. Production of reactive oxygen species (ROS) was measured using fluorometric assays. Westernblotting for PARP, caspase-3 and phosphorylated as well as unphosphorylated akt and erk1/2 was performed. Results: Hypoxia led to morphological signs of cell damage (Fig. 1B). Under hypothermia, LDH measurements revealed a significant LDH increase earliest at 25h after the hypoxic insult ( $<<0.01$ vs normoxia, Fig. 2), while under normothermic conditions comparable cell damage was already detectable after $17 \mathrm{~h}$ (ESA 2015 , poster presentation). The post-hypoxic application of $30 \mathrm{ng} / \mathrm{ml}$ of 2 -IB significantly reduced the hypoxia-induced LDH release to levels found under normoxia $(0 \mathrm{ng} / \mathrm{ml}, p<0.001 ; 10 \mathrm{ng} / \mathrm{ml}, \mathrm{p}<0.001 ; 30 \mathrm{ng} / \mathrm{ml}, \mathrm{p}>0.05 ; 50 \mathrm{ng} / \mathrm{ml}$, $\mathrm{p}<0.01 ; 100 \mathrm{ng} / \mathrm{ml}, \mathrm{p}<0.001 ; 300 \mathrm{ng} / \mathrm{ml}, \mathrm{p}<0.01$ all vs normoxia; Fig. $3 \mathrm{LDH}$ ). Application of $2-\mathrm{IB}$ (10 and 30ng/ml) after hypoxia reduced the hypoxia-induced ROS production under hypothermic conditions (hypoxia: $p<0.001$ vs normoxia; hypoxia+2-IB: $p<0.01$ vs normoxia for 10 and $30 \mathrm{ng} / \mathrm{ml}$ of 2 -IB). Higher concentrations of 2 -IB were less effective in reducing hypoxia-induced ROS generation (Fig. 3 ROS). Culture medium concentrations of hydrogen peroxide were 9 -fold increased by hypoxia under hypothermia ( $\mathrm{p}<0.001$ vs normoxia) but not influenced by post-hypoxic application of 2-IB (data not shown). Cleavage of PARP, akt phosphoprylation and caspase-3 expression were by trend increased after the hypoxic insult, while hypoxia significantly enhanced the phosphorylation of the pro-survival kinase erk $1 / 2$ ( $p<0.05$ vs normoxia). However, the addition of 2 -IB under hypothermia did not influence cleavage, expression or phosphorylation of any of the mentioned molecules (Fig. 4).
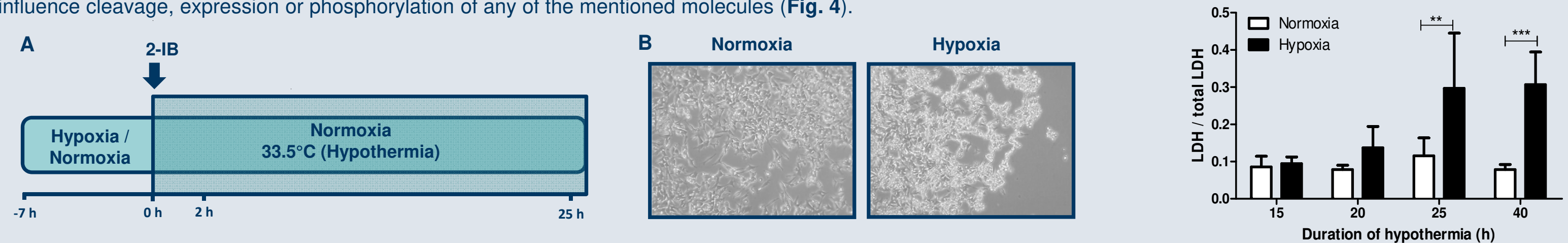

Fig. 1 Experimental setting A-Human neuroblastoma cells, IMR-32, were subjected to hypoxia for 7 h or normoxia (control). After the insult, fresh medium containing vehicle (citrate $1 \%$ ) or $2-I B$ at clinically relevant concentrations $(10,30,50,100$ and $300 \mathrm{ng} / \mathrm{ml})$ were applied to the cultures, under hypothermic conditions $\left(33.5^{\circ} \mathrm{C}\right)$. At different time points after the insult, cell protein or the respective cell culture media were used to evaluate cell protein expression by westernblotting (at $2 \mathrm{~h}$ and $25 \mathrm{~h}$ ), cell viability by $\mathrm{LDH}$ release (at $25 \mathrm{~h}$ ) and ROS production (at 25h). B- Cell morphology under normoxia and hypoxia by optical microscopy.

LDH
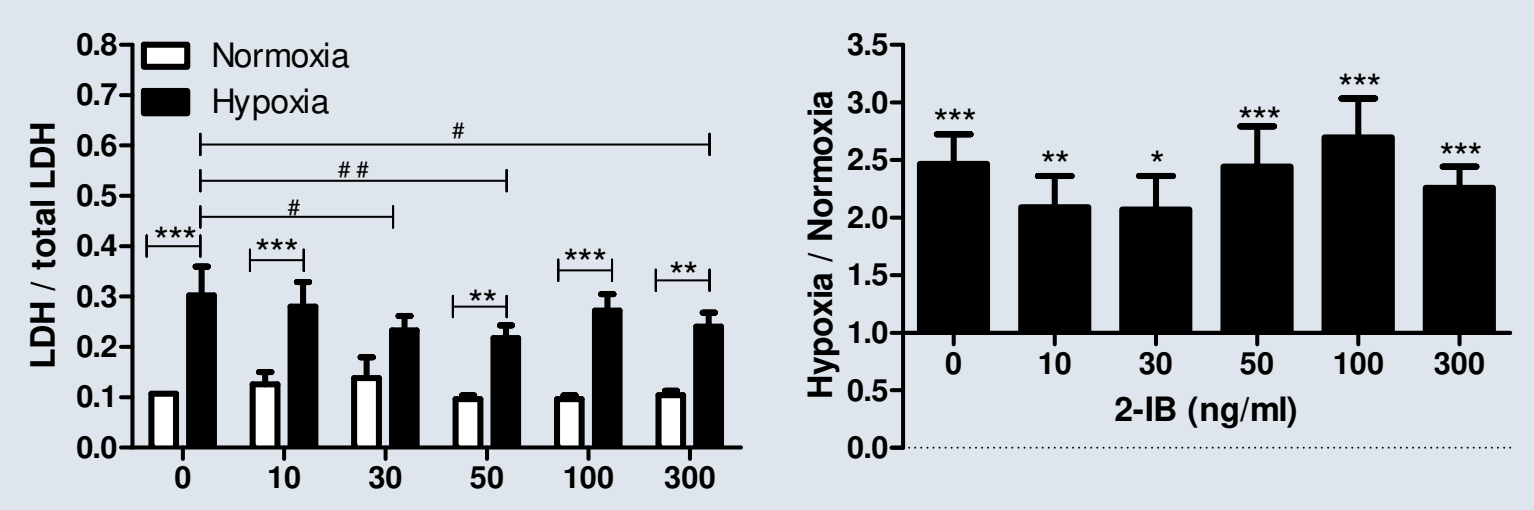

2-IB (ng/ml)

ROS
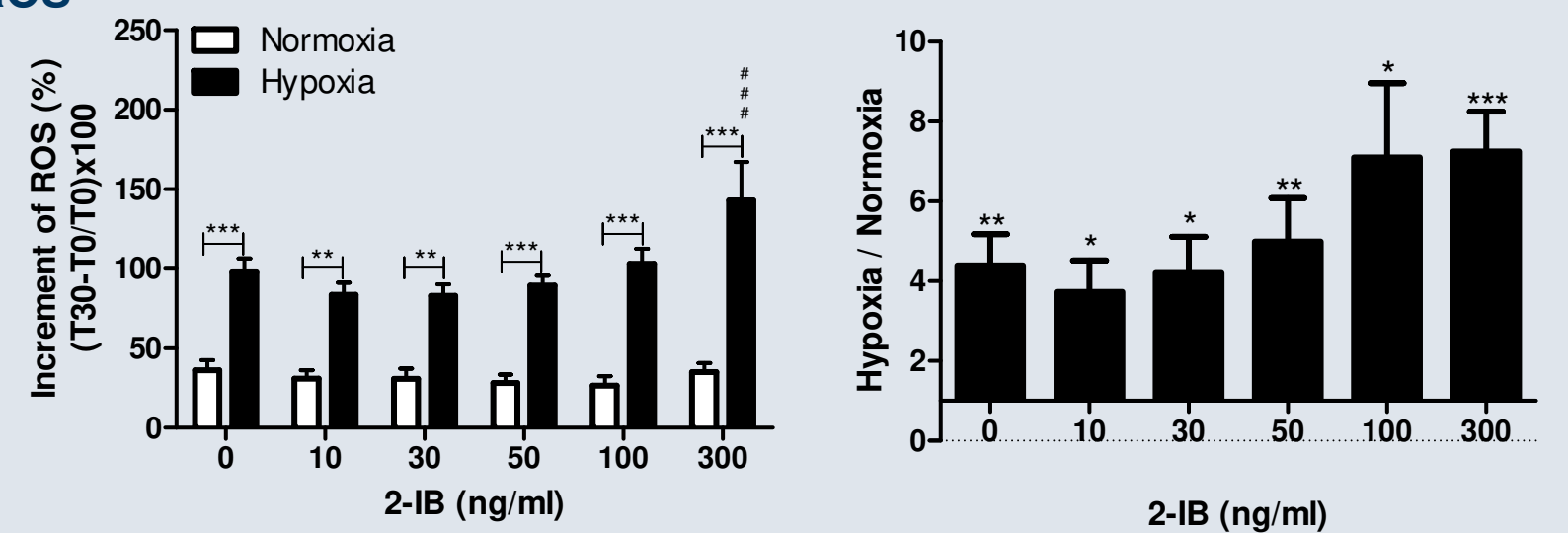

Fig. 3 Cell damage (LDH) and production of reactive oxygen species (ROS). Vehicle (citrate 1\%) as control or increasing concentrations of 2-IB $(0-300 \mathrm{ng} / \mathrm{ml})$, were applied on IMR-32 after the insult (7h hypoxia) under hypothermic conditions $\left(33.5^{\circ} \mathrm{C}\right)$. 2-IB showed protection against hypoxia at $30 \mathrm{ng} / \mathrm{ml}$ and this protective effect was lost by increasing the concentration of $2-1 B$ to $100 \mathrm{ng} / \mathrm{ml}\left({ }^{*}: P<0.05 ;{ }^{* *}: P<0.01 ; * * *: P<0.001 ; \#: P<0.05 ; \# \#\right.$ : $P<0.01 ; n=8 ; 2$ way ANOVA). 10 and $30 \mathrm{ng} / \mathrm{ml}$ of $2-1 B$ lead to a diminution of the production of $R O S{ }^{*}: P<0.05$; ${ }^{* *}: P<0.01 ; * * *: P<0.001 ; \# \# \#: P<0.001, n=9 ; 2$ way ANOVA).

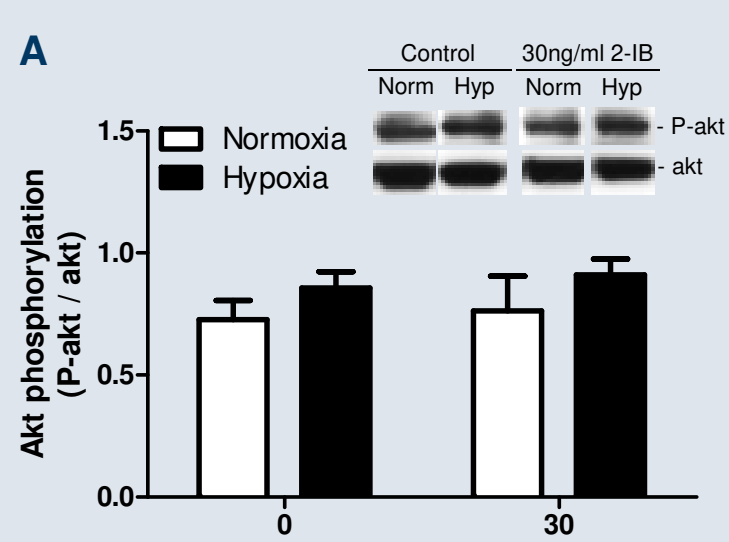

$2-1 \mathrm{~B}(\mathrm{ng} / \mathrm{ml})$

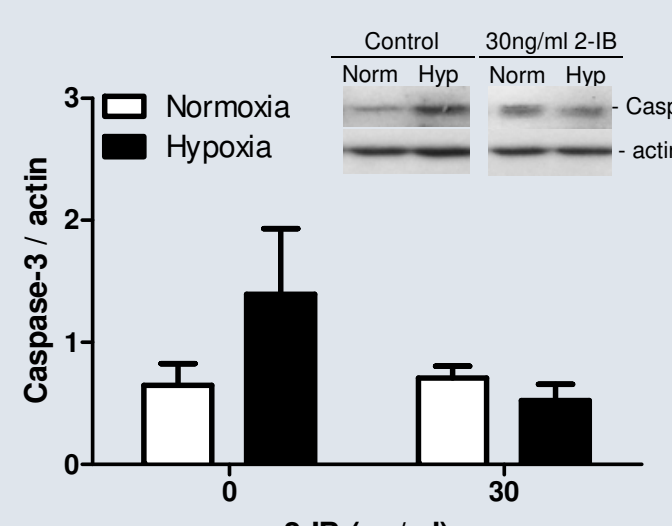

$2-\mathrm{IB}(\mathrm{ng} / \mathrm{ml})$

Fig. 4 Protein expression, cleavage and phosphorylation of pro-survival kinases. Phosphorylation of cell survival proteins (akt und erk) was evaluated by Westernblots using protein isolated $2 h$ after hypoxia $(\boldsymbol{A}, \boldsymbol{B})$. Neither hypoxia nor 2-IB effected the phosphorylation of akt (A). The presence of 2-IB did not change the hypoxia induced protein phosphorylation of erk (B), and reduced by trend the upregulation of caspase-3 induced by hypoxia (C). The cleavage of PARP from $25 \mathrm{~h}$ protein after the end of insult, was slightly upregulated by hypoxia but 2-IB does not exert any effect on the cleavage of PARP (D). ( ${ }^{*}: P<0.05 ; n=4-5 ; 2$ way ANOVA).

Conclusion

2-IB reduces hypoxia-induced neuronal cell damage in vitro under hypothermic conditions. Combining hypothermia with 2-IB might represent a promising treatment strategy for reducing hypoxia-induced neuronal injury. 